
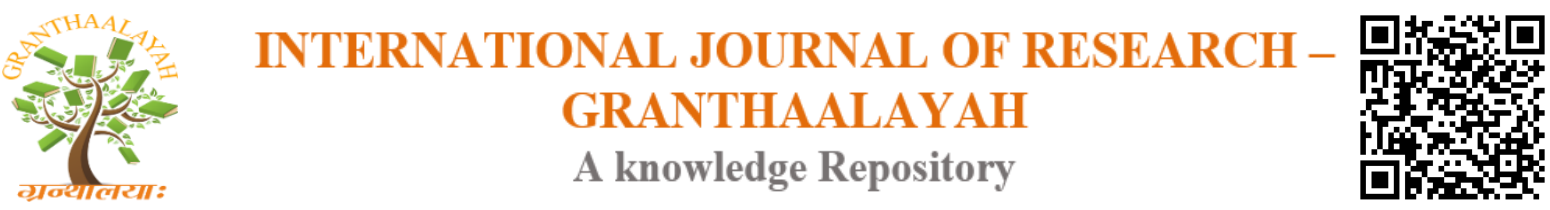

Science

\title{
SEEDS, PODS AND PETIOLE GLAND'S CHARACTERISTICS OF LEUCAENA SPP. ANALYTICAL STUDY (A)
}

\author{
Younis Saied Hassan Al-Bugg *1 \\ ${ }^{* 1}$ Assistant Professor, Technical Institute of Mosul / Iraq
}

\begin{abstract}
Twenty-two species were extracted from the Leucaena Spp. Data were collected on their characteristics, which differed from each other and were classified accordingly. Statistical analysis revealed that there were many differences between species in some traits; each type is itself in other qualities. Therefore, we presented the qualities that need to be described in order to identify differences. The study included the qualities related to seeds, pods and petiole gland. The seeds were aligned in Pods in three forms, while the shape of the seed came in two types. Only two types of species differed in the status of the opening of the pod (dehiscence). As for the thickness of the wall of the Pods, the species varied greatly, and the highest was the Papery. The rate of openness of the Pods was very high at $90.9 \%$ for one margin. The partitioning between seeds within Pods did not register more than two types, and it tended to have no partition by $72.7 \%$. Only two shapes were distinguished in terms of the clarity of the seed chamber on the surface of the pods and 16 times the uncertainty was repeated ( not partitioned ), leaving 6 replicates of the possible type of clarity ( partitioned ). The colors of Pods differed very much, and each type had its own color except for some exceptions. The most frequent color was (To Orange Brown) with five replicates and the color (Mid Orange Brown) four times and the remaining types remained independent of colors. There was a high correlation between seed and pods traits and in some cases reached $90 \%$ at the probability of $1 \%$. The length of the seed ranged between $4.9 \mathrm{~mm}$ - $10.6 \mathrm{~mm}$ but distributed over all types of tree under study. Each seed type had a specific seed length. The correlation coefficient between seed width and seed length was high at a probability of $1 \%$ to 0.775 . Seeds / $\mathrm{Kg}$ was varied even within one species and was between 8700 - 70000 seeds / kg. There were only two forms that showed the accompaniment of the gland on the throat while three forms of the gland type were recorded but the gland height had a variety of forms.
\end{abstract}

Keywords: Leucaena; Pods; Petiole Glands; Fast Growth; Vesture; Distinguish Characteristic.

Cite This Article: Younis Saied Hassan Al-Bugg. (2017). "SEEDS, PODS AND PETIOLE GLAND'S CHARACTERISTICS OF LEUCAENA SPP. ANALYTICAL STUDY (A)." International Journal of Research - Granthaalayah, 5(12), 421-434. https:// doi.org/10.29121/granthaalayah.v5.i12.2017.529. 


\section{Introduction}

The Lucena tree belongs to the family of Fabaceae and under the family Mimosoideae and genus Leucaena, and the tree of Lucena is lessed with all the meanings of the word because of its diversity (distinguishing it from more than 22 species) and the multiple uses and benefits, while benefiting the population in Africa rich food In proteins, others use them in bee keeping because they have colorful flowers attractive to the bees and rich at the same time with food and have a very large place in the livestock breeders use their leaves as a feed. Marcos (2014). Researchers estimate it contains up to $35 \%$ protein and its use has increased milk production by $14 \%$. (Jones, 1994). Its rapid growth also has a major impact on its selection as windbreaks and fences for gardens, farms and intermediate carrots in cities. This tree has a high capacity to produce seeds in very large quantities may reach 70000 seeds / $\mathrm{kg}$ in some types and that these seeds have a very high germination capacity and in a very short time as their seeds germinate at 3-5 months from the date of collection and replenished naturally under different circumstances and often What we see is the seedlings under the mother tree as soon as they reach the ground making them of important developmental value (Hughes, 1998a, b). The specific gravity of the species varies greatly. While we have the types of average gravity (0.543) we find types of high density and high specific gravity of up to (0.853) which drives users to use them in different fields such as columns of houses, buildings, paper industry, furniture, So many, especially the least density. Leucaena came from the Greek sections Leuc (white) and Caen (new) according to the color of Venus. (Leucocephala) is derived from Leu, meaning white and Cephala (Sadawe, 2015). Although native to America and Mexico, it is now spread throughout the world to adapt to the conditions in which it is grown. The cultivated area of these trees is estimated at 2-5 million hectares around the world (Shaik, 2009), And at the level of Nineveh province, we see them spread in almost all neighborhoods, albeit individually, but they are of good size and great freshness, indicating the appropriateness of the conditions that help in their growth, as well as the natural renewal, which is only when the appropriate environmental conditions for the growth of the species. One of the most important uses of this tree is the tendency of researchers to take advantage of them in the extraction of medical treatments and the pharmaceutical industry (Meena 2013). For one reason or another, we have noticed the interest of most researchers in a specific type (Leucaena leucocephala) the species has many traits that share with other species. From this point of view, our interest in the study of these species and the collection of data related thereto and the study of morphological and anatomical as much as possible, seeking to make it the tree of the city that distinguishes it from the rest of the cities and make use of its different uses.

\section{Materials and Methods}

From the book "Leucaena A Genetic Resources Handbook" (Hughes, Colin E. (1998), which explains the characteristics of the various species of the Lucena tree, we collected, arranged, tabulated and entered data into the computer using the Excel system. And twenty two distinct species with characteristics that is similar and varies from one type to another (Table 1). The characteristics of the species were many and varied and reached more than 60 characteristics, including morphological, anatomical and environmental. After completing the data, the characteristics of all species (with their discriminatory importance) were excluded. It is useless to compare them, as well as to exclude the characteristics in which missing observations exceed $25 \%$ of the data, because they cannot be compensated by computer as qualitative qualities And 
not the quantity) and then we took the most different or varied characteristics of the statistical operations to calculate the frequency of the character by type and the calculation of the percentages, and this was done using the system used worldwide statistical (SPSS) and because of clear differences in the analysis we have seen a statistical process is important to measure The extent of the relationship between the variables and the effect of the attributes in some of them by calculating The correlation coefficient (r), which measures the strength of the relationship between two variables, from which the $\mathrm{R}^{2}$ is calculated (Al-Rawi, Khashi Mahmood, Abdulaziz Khalaf Allah, 1980) gives the actual effect of the independent variable in the dependent variable. The results are placed in the correlation matrix so that any user can read the value of relationship between the variables and then judge the amount of effect. Then we explained the following in this study: 1. Seeds. 2. Pods. 3. Characteristics of petiol glands.

Table 1: Spp. Studied

\begin{tabular}{|ll|}
\hline Sequence & Species of Leucaena spp \\
1 & L. collinsii Britton \& Rose \\
2 & L. confertiflora S. Zarate \\
3 & L. cuspidata Stmdley \\
4 & L. diversifolia (Schltdl.) Benth. \\
5 & L. esculenta (Sesse \& Moc. Ex \\
6 & L. greggii S. Watson \\
7 & L. involucrata S. Zarate \\
8 & L. lanceolata S. Watson \\
9 & L. lempirana C.B. Hughes \\
10 & L. leucocephala (Lam.) de Wit \\
11 & L. macrophylla Benth. \\
12 & L. magnifica (C.E. Hughes) C.E. \\
13 & L. matudae (S. Zarate) C.E. \\
14 & L. multicapitula Schery \\
15 & L. pallida Britton \& Rose \\
16 & L. pueblana Britton \& Rose \\
17 & L. pulverulenta (Schltdl.) Benth. \\
18 & L. retusa Benth. \\
19 & L. salvadorensis Standley ex \\
20 & L. shannonii 1.0. Smith \\
21 & L. trichandra (Zucc.) Urban \\
22 & L. trichodes (lacq.) Benth. \\
\hline
\end{tabular}

Species extracted from handbook written by (Hughes, 1998).

\section{Results and Discussions ${ }^{1}$}

After the statistical analysis of the data, we found it appropriate, but it is necessary to classify the results to present the specifications and characteristics related to the attributes and percentages of the characteristics of the characteristic. In order to facilitate the task of the reader, we have

${ }^{1}$. All folowing tables were done by Auther . 
decided to include the tables relating to each attribute immediately after the explanation as follows:

\subsection{First: Seed Properties}

\subsubsection{Seeds Aligned in Pods}

This characteristic could be divided into three forms of alignment:

- Transversely

- Longitudinally

- Obliquely

From Table (2) we find the superiority of the first type on each of the other types of longitudinal and diagonal, each repeated 16, 2 and 4 times and percentages of $72.2,9.1$ and 18.2\%, respectively.

Table 2: Frequencies and percentages of seed alignment types in pods

\begin{tabular}{|lllll|}
\hline Valid & Frequency & Percent & Valid percent & Cumulative Percent \\
Transversely & 16 & 72.7 & 72.7 & 72.7 \\
Longitudinally & 2 & 9.1 & 9.1 & 81.8 \\
Obliquely & 4 & 18.2 & 18.2 & 100.0 \\
Total & 22 & 100.0 & 100.0 & \\
\hline
\end{tabular}

\subsubsection{Seed Shape Group}

When calculating duplicates as such, we have two distinct forms as follows:

- Circular to Ovate

- Rhomboidal

Both Figs. 16 of the first type and 6 times of the second form have been repeated with a sovereignty of approximately three times. And to convert them to a percentage of $72.7 \%$ and $27.3 \%$, respectively. Table (3). Krisnawati et al. (2011) points out that when the color of the fruit becomes dark brown, the seeds take a triangular or often irregular form, indicating that the seeds can germinate after two to three weeks and can be transferred to 8-12 weeks of plastic bags.

Table 3: The frequencies of seed Shape

\begin{tabular}{|lllll|}
\hline Valid & Frequency & Percent & Valid Percent & Cumulative Percent \\
circular to ovate & 16 & 72.7 & 72.7 & 72.7 \\
Rhomboidal & 6 & 27.3 & 27.3 & 100.0 \\
Total & 22 & 100.0 & 100.0 & \\
\hline
\end{tabular}

\subsubsection{Seed Length $\mathrm{mm}$.}

We noted a great independence for this trait itself, as we did not notice significant replicas of the studied species. The length of the seed ranged from $4.9 \mathrm{~mm}$ to $10.6 \mathrm{~mm}$, meaning that the longer seeds were twice as long as the lower length. All species are found in Annex 1. 


\subsubsection{Seed Width mm.}

This characteristic went exactly as it did in the previous character (seed length) and repeated readings were rare. In the study of correlation between the two values, the value of the coefficient was significant at the probability level of $1 \%$ and the value of 0.755 . The respective values are set out in Annex 2.

\subsubsection{Number of Seeds / $\mathrm{kg}$.}

The correlation coefficient between this function and the seed length and width of the seed showed a high significance at the $1 \%$ probability level. The value of the coefficient with seed length was 0.828 while the value of 0.740 was recorded for the seed width. We note the independence of species in this capacity too, since each species had almost a few seeds per kilogram of its own. It is no secret that the number of seeds per kilogram is inversely proportional to both length and width of the seed. It is important to note that the variation in the number of seeds per kilogram was obtained even within one species depending on the age, size and environment of the tree. Therefore, we calculated averages to be dealt with during the analysis process. The average number of seeds per kilogram of 7800 was given by the Lucena cuspidata Stmdley tree, while the highest was 70,000 seeds / $\mathrm{kg}$ given by the Lucena L. bifida L. diverifolia (Schltdl) tree. It is a very wide range. Annex (3).

\section{Second: Pods}

\subsubsection{Pod Shape Group}

From Table (4), the shape of the pods was the same as that of the seed shape. The same frequencies $(16,6)$ were recorded for both long and long rectangle shapes.

Table 4: Frequencies of pod shape

\begin{tabular}{|lllll|}
\hline Valid & Frequency & Percent & Valid Percent & Cumulative Percent \\
linear oblong, broader & 16 & 72.7 & 72.7 & 72.7 \\
narrow linear & 6 & 27.3 & 27.3 & 100.0 \\
Total & 22 & 100.0 & 100.0 & \\
\hline
\end{tabular}

\subsubsection{Pod Dehiscence}

Table (5) shows the vast difference between the repetitions of the first form and the second form as follows:

- Two margins

- One margin

The first form (One margins) has exceeded the second form (two margin) ten times and repeated 20 times, while the other repeated only two times. It should be noted that such qualities, although distinct, are not reliable in distinguishing between different species to share many species in them. Table (5). It should be noted that this status did not have a significant correlation with the rest of the attributes related to the seeds. 
Table 5: The shape of the Pod dehiscence

\begin{tabular}{|lllll|}
\hline Valid & Frequency & Percent & Valid Percent & Cumulative Percent \\
2 margins & 2 & 9.1 & 9.1 & 9.1 \\
1 margin & 20 & 90.9 & 90.9 & 100.0 \\
Total & 22 & 100.0 & 100.0 & \\
\hline
\end{tabular}

\subsubsection{Wall Thickness}

The thickness of the wall varied in this capacity, the most frequently known as papery and seven repetitions, followed by the papery to leathery form with four repetitions and then the Leatherery with three repetitions. Table (6) presents the frequencies and percentages represented by each of the three species. This attribute has been followed in the same way as the previous characteristic in the insignificance of correlation with the other qualities related to seeds and pods.

Table 6: Pods wall thickness mm. frequencies

\begin{tabular}{|lllll|}
\hline Valid & Frequency & Percent & Valid Percent & Cumulative Percent \\
papery or leathery & 4 & 18.2 & 19.0 & 19.0 \\
Thick, leathery or almost & 1 & 4.5 & 4.8 & 23.8 \\
woody & 2 & 9.1 & 9.5 & 33.3 \\
Thin, papery & 2 & 9.1 & 9.5 & 42.9 \\
leathery or slightly woody & 3 & 13.6 & 14.3 & 57.1 \\
Leathery & 7 & 31.8 & 33.3 & 90.5 \\
Papery & 1 & 4.5 & 4.8 & 95.2 \\
slightly thick and leathery & 1 & 4.5 & 4.8 & 100.0 \\
strongly leathery or almost & 1 & 95.5 & 100.0 & \\
woody & 21 & 4.5 & & \\
Total & 1 & 100.0 & & \\
Missing System & 22 & & & \\
Total & & & \\
\hline
\end{tabular}

\subsubsection{Pod Vesture Surface}

Six types of glabrous surface were similar. And three repetitions of the glabrous and slightly lustrous species, while sometimes the shape of the lustrous and glabrous or dense velvety hairs and the shape densely covered in velvety hairs are repeated twice each. Table (7).

\subsubsection{Pod Partitioning Between Seeds}

The order in this category tended to favor the absence of clear divisions (ie, there were no separations between the seeds inside the pods), 16 times and $72.7 \%$, while the duplicates for the emergence of divisions were clearly six replicates and $27.3 \%$, respectively. Table (8). 
Table 7: Frequencies of pod vesture surface

\begin{tabular}{|c|c|c|c|c|}
\hline Valid & Frequency & Percent & Valid Percent & Cumulative Percent \\
\hline & 2 & 9.1 & 9.1 & 9.1 \\
\hline Glabrous & 6 & 27.3 & 27.3 & 36.4 \\
\hline $\begin{array}{l}\text { sometimes lustrous glabrous or } \\
\text { dense velvety hairs }\end{array}$ & 2 & 9.1 & 9.1 & 45.5 \\
\hline $\begin{array}{l}\text { glabrous or occasionally } \\
\text { sparsely hairy }\end{array}$ & 1 & 4.5 & 4.5 & 50.0 \\
\hline glabrous or pubescent & 1 & 4.5 & 4.5 & 54.5 \\
\hline $\begin{array}{l}\text { sometimes lustrous, glabrous or } \\
\text { covered in dense velvety hairs }\end{array}$ & 1 & 4.5 & 4.5 & 59.1 \\
\hline glabrous or dense velvety hairs & 2 & 9.1 & 9.1 & 68.2 \\
\hline $\begin{array}{l}\text { nearly glabrous or dense } \\
\text { velvety hairs }\end{array}$ & 1 & 4.5 & 4.5 & 72.7 \\
\hline $\begin{array}{l}\text { glabrous and slightly lustrous or } \\
\text { dense white velvety hairs }\end{array}$ & 3 & 13.6 & 13.6 & 86.4 \\
\hline densely covered in velvety hairs & 2 & 9.1 & 9.1 & 95.5 \\
\hline slightly lustrous glabrous & 1 & 4.5 & 4.5 & 100.0 \\
\hline Total & 22 & 100.0 & 100.0 & \\
\hline
\end{tabular}

\subsubsection{Seed Chamber Appearance on Pod Walls}

The number of 16 in the duplicates is the most frequent; as it is repeated in more than one attribute and we will attempt to explain this through statistical relations. The seed chambers within the pods have been repeated 16 times, while the possibilities clearly distinguish six times. Table (9). We also note here that this distinction cannot be used to distinguish between species as a primary feature.

Table 8: Frequencies of Partitioning between seeds

\begin{tabular}{|lllll|}
\hline Valid & Frequency & Percent & Valid Percent & Cumulative Percent \\
n.partitioned & 16 & 72.7 & 72.7 & 72.7 \\
partitioned & 6 & 27.3 & 27.3 & 100.0 \\
Total & 22 & 100.0 & 100.0 & \\
\hline
\end{tabular}

Table 9: Seed chamber appearance on pod walls

\begin{tabular}{|lllll|}
\hline \multicolumn{1}{|c}{ Valid } & Frequency & Percent & Valid Percent & Cumulative Percent \\
not clearly visible nor raiser & 16 & 72.7 & 72.7 & 72.7 \\
clearly visible or raise & 6 & 27.3 & 27.3 & 100.0 \\
Total & 22 & 100.0 & 100.0 & \\
\hline
\end{tabular}

\subsubsection{Ripe Pod Color}

May not have that high advantage in differentiating between species. We found it appropriate to study this trait to see how it relates to the characteristics and characteristics studied. We note that there is a loss in the data of two species of total (22) species. From table (10), there is a wide 
variety of color and may be due to the area planted with trees and the extent of rise and fall in sea level or other environmental factors. The most frequent color in the study was the color of Orange Brown and repeated (5 times) to form $22.7 \%$ while the color closest to it was orange with four replicates while the rest of the colors were distributed as if each tree had its own color. It should be noted here that it is important to distinguish species as they are not often associated with other species. Since seeds and pods had these characteristics, we found from Table (14) the close correlation and at the $1 \%$ probability level. In some cases, the value of the laboratory has exceeded $90 \%$. We found that the coefficient is more than $85 \%$ in most cases. This means that the dependent variable character has affected the independent by $85 \%$, while $15 \%$ of other factors are not relevant to the study (Al-Rawi, 1980).

\subsubsection{Pod Length cm.}

It is characteristic that the species rarely participated and repeated three times and two times for the higher length of $24 \mathrm{~cm}$ and the lowest $9 \mathrm{~cm}$ respectively, while the rest of the species independent themselves as shown in Appendix (4) as well as for the presentation of Qurna, The values were limited between $1 \mathrm{~cm}-2.9 \mathrm{~cm}$. It is also a relatively wide range. We also note that the higher width is three times the size of the other species, but it is useful in the process of differentiation between species. Annex (5).

\section{Third: Petiol Glands}

\subsection{Petiole Gland Attachment}

In Table 11, there is a clear and significant advantage between the forms of accompaniment. The form (unstalked and most flat) is repeated 17 times and $73.3 \%$ with 5 recurrences and $22.7 \%$ in the form of Stacked.

Table 10: Frequencies of ripe pod color

\begin{tabular}{|lllll|}
\hline Valid & Frequency & Percent & Valid Percent & Cumulative Percent \\
& 2 & 9.1 & 9.1 & 9.1 \\
dark brown & 1 & 4.5 & 4.5 & 13.6 \\
dark brown or reddish-brown & 1 & 4.5 & 4.5 & 18.2 \\
dark maroon or maroon- & 1 & 4.5 & 4.5 & 22.7 \\
brown & & & & \\
dark reddish-brown & 1 & 4.5 & 4.5 & 27.3 \\
lustrous rich orange-brown & 1 & 4.5 & 4.5 & 31.8 \\
mid - to orange brown & 5 & 22.7 & 22.7 & 54.5 \\
mid orange-brown & 4 & 18.2 & 18.2 & 72.7 \\
mid reddish or orange-brown & 2 & 9.1 & 9.1 & 81.8 \\
mid reddish-brown & 1 & 4.5 & 4.5 & 86.4 \\
pale to dark orange-brown & 1 & 4.5 & 4.5 & 90.9 \\
\hline
\end{tabular}




\begin{tabular}{|lllll|}
\hline $\begin{array}{l}\text { pale yellow or deep reddish- } \\
\text { brown }\end{array}$ & 1 & 4.5 & 4.5 & 95.5 \\
rich orange-brown & 1 & 4.5 & 4.5 & 100.0 \\
Total & 22 & 100.0 & 100.0 & \\
\hline
\end{tabular}

Table 11 :Frequencies of Petiole Gland Attachment

\begin{tabular}{|lllll|}
\hline Valid & Frequency & Percent & Valid Percent & Cumulative Percent \\
unstalked, flatter & 17 & 77.3 & 77.3 & 77.3 \\
stalked, stipitate & 5 & 22.7 & 22.7 & 100.0 \\
Total & 22 & 100.0 & 100.0 & \\
\hline
\end{tabular}

\subsection{Petiole Gland Type}

It was divided into three categories, but the highest was Convex, nine replicates, $40.9 \%$ followed by Concave, eight recurrences, 36.4\%, while the last form was Elect, with 5 recurrences, $22.7 \%$ (Table 12). We note that the external appearance of the gland showed complete independence of all species in the form of the apparent form of the gland Gland morphology as each species has an independent form. In other words, there are no two species involved in this function, which is a very positive function in the process of distinguishing between species in the case of a classification key for species. Table 12a

Table 12a: Frequencies of petiol gland morphology

\begin{tabular}{|c|c|c|c|c|}
\hline Valid & Frequency & Percent & Valid Percent & Cumulative Percent \\
\hline $\begin{array}{l}\text { circular-elliptic, deep cup- } \\
\text { shaped }\end{array}$ & 1 & 4.5 & 4.5 & 4.5 \\
\hline cylindrical/peg-shaped & 1 & 4.5 & 4.5 & 9.1 \\
\hline $\begin{array}{l}\text { discoid, shallow cup-shaped, } \\
\text { elliptic or rounded triangular }\end{array}$ & 1 & 4.5 & 4.5 & 13.6 \\
\hline Elliptic & 1 & 4.5 & 4.5 & 18.2 \\
\hline $\begin{array}{l}\text { Elliptic, dome-shaped, round } \\
\text { conical }\end{array}$ & 1 & 4.5 & 4.5 & 22.7 \\
\hline $\begin{array}{l}\text { elliptic, dome-shaped, } \\
\text { rounded }\end{array}$ & 1 & 4.5 & 4.5 & 27.3 \\
\hline $\begin{array}{l}\text { Elliptic, dome-shaped, } \\
\text { rounded conical }\end{array}$ & 1 & 4.5 & 4.5 & 31.8 \\
\hline $\begin{array}{l}\text { elliptic, large shallowly } \\
\text { concave, cup-shaped }\end{array}$ & 1 & 4.5 & 4.5 & 36.4 \\
\hline elliptic, rounded conical & 1 & 4.5 & 4.5 & 40.9 \\
\hline elliptic, rounded conical & 1 & 4.5 & 4.5 & 45.5 \\
\hline elliptic, shallow cup-shaped & 1 & 4.5 & 4.5 & 50.0 \\
\hline $\begin{array}{l}\text { elliptical, rounded conical or } \\
\text { dome-shaped }\end{array}$ & 1 & 4.5 & 4.5 & 54.5 \\
\hline $\begin{array}{l}\text { oblong, irregularly lumpy, } \\
\text { pore usually invisible }\end{array}$ & 1 & 4.5 & 4.5 & 59.1 \\
\hline $\begin{array}{l}\text { round discoid or shallow } \\
\text { creator, shaped }\end{array}$ & 1 & 4.5 & 4.5 & 63.6 \\
\hline
\end{tabular}




\begin{tabular}{|lllll|}
\hline $\begin{array}{l}\text { round or rounded triangular, } \\
\text { cup-shaped concave or deeply } \\
\text { creator-shaped, sometimes }\end{array}$ & 1 & 4.5 & 4.5 & 68.2 \\
$\begin{array}{l}\text { double gland } \\
\text { rounded elliptic, dome-shaped }\end{array}$ & 1 & & & \\
rounded-elliptic, dome- & 1 & 4.5 & 4.5 & 72.7 \\
$\begin{array}{l}\text { shaped, round conical } \\
\text { slender, columnar }\end{array}$ & 1 & 4.5 & 4.5 & 77.3 \\
shallow concave, elliptic & 1 & 4.5 & 4.5 & 81.8 \\
short cylindrical peg-shaped & 1 & 4.5 & 4.5 & 86.4 \\
short stalked, peg-shaped & 1 & 4.5 & 4.5 & 90.9 \\
tall, slender, cylindrical & 1 & 4.5 & 4.5 & 95.5 \\
Total & 22 & 4.5 & 4.5 & 100.0 \\
\hline
\end{tabular}

Table 12b: Frequencies of petiole gland type

\begin{tabular}{|lllll|}
\hline Valid & Frequency & Percent & Valid Percent & Cumulative Percent \\
Convex & 9 & 40.9 & 40.9 & 40.9 \\
Concave & 8 & 36.4 & 36.4 & 77.3 \\
Erect & 5 & 22.7 & 22.7 & 100.0 \\
Total & 22 & 100.0 & 100.0 & \\
\hline
\end{tabular}

\subsection{Petiole Gland Height mm.}

The height of ( less than $1 \mathrm{~mm}$ ) is greater than $1 \mathrm{~mm}$ at 12 frequencies followed by height (1 $\mathrm{mm}$ ) with seven repetitions while elevations $1.5,2$ and $2.5 \mathrm{~mm}$ with one recurrence to represent $54.5,31.8,4.5,4.5,4.5$ and $4.5 \%$ Respectively .

Table 13: Frequencies of petiole gland height

\begin{tabular}{|lllll|}
\hline Valid & Frequency & Percent & Valid Percent & Cumulative Percent \\
0.65 & 1 & 4.5 & 4.5 & 4.5 \\
1 & 7 & 31.8 & 31.8 & 36.4 \\
1.5 & 1 & 4.5 & 4.5 & 40.9 \\
2 & 1 & 4.5 & 4.5 & 45.5 \\
2.5 & 1 & 4.5 & 4.5 & 50.0 \\
less than 1 & 11 & 50.0 & 50.0 & 100.0 \\
Total & 22 & 100.0 & 100.0 & \\
\hline
\end{tabular}

Table 14: Correlation Matrix for Seeds and Pods variables

\begin{tabular}{|l|l|l|l|l|l|l|}
\hline \multicolumn{1}{|c|}{ Variables } & $\begin{array}{c}\text { seed } \\
\text { aligned } \\
\text { in pod }\end{array}$ & \multicolumn{1}{|c|}{$\begin{array}{c}\text { pod wall } \\
\text { thickness }\end{array}$} & $\begin{array}{c}\text { pod } \\
\text { dehiscence }\end{array}$ & $\begin{array}{c}\text { seed chamber } \\
\text { appearance on } \\
\text { pod walls }\end{array}$ & $\begin{array}{c}\text { Seed } \\
\text { length } \\
\text { mmm }\end{array}$ & $\begin{array}{c}\text { Seed } \\
\text { width } \\
\text { mmm }\end{array}$ \\
\hline $\begin{array}{l}\text { seed aligned in } \\
\text { pod }\end{array}$ & 1 & .287 & .184 & $.949^{* * *}$ & -.021 & .032 \\
\hline $\begin{array}{l}\text { pod wall } \\
\text { thickness }\end{array}$ & 1 & $.440^{*}$ & .333 & -.281 & -.312 \\
\hline
\end{tabular}




\begin{tabular}{|l|l|l|l|l|l|}
\hline pod dehiscence & & 1 & .194 & -.282 & $-.526^{*}$ \\
\hline $\begin{array}{l}\text { seed chamber } \\
\text { appearance on } \\
\text { pod walls }\end{array}$ & & & 1 & .001 & .064 \\
\hline $\begin{array}{l}\text { Seed length } \\
\text { mm }\end{array}$ & & & & & 1 \\
\hline $\begin{array}{l}\text { Seed width } \\
\text { mm }\end{array}$ & & & & & 1 \\
\hline $\begin{array}{l}\text { **. Correlation is significant at the 0.01 level (2-tailed). } \\
\text { *. Correlation is significant at the 0.05 level (2-tailed). }\end{array}$ \\
\hline
\end{tabular}

\section{Conclusions and Recommendations}

According to results shown

1) There are great differences between species in some characteristics, while it becomes in very low limits in others.

2) Variations in these species, leads to possibility of planting at least two species in Mosul (a state in Iraq).

3) The tree Laucaena Spp. Is a very useful one whereas it can be used as food for humans, foliage, wood industries and so.

4) Colledges of Agriculture and Forestry advised to plant this tree and make stands to occupy cities and students to do their researchs about it.

\section{Acknowledgements}

My colleague, and old friend who hold the very first idea about this research and collected data from the handbook, Mr. Amged Khalil Al-Mashhadani the director of agricultural laboratories in agric. Office in Mosul /Iraq . Thank you very much .

Annex 1: Seed length Mm.

\begin{tabular}{|lllll|}
\hline Valid & Frequency & Percent & Valid Percent & Cumulative Percent \\
4.90 & 1 & 4.5 & 4.5 & 4.5 \\
5.50 & 1 & 4.5 & 4.5 & 9.1 \\
6.50 & 1 & 4.5 & 4.5 & 13.6 \\
6.85 & 1 & 4.5 & 4.5 & 18.2 \\
6.95 & 1 & 4.5 & 4.5 & 22.7 \\
7.15 & 1 & 4.5 & 4.5 & 27.3 \\
7.20 & 1 & 4.5 & 4.5 & 31.8 \\
7.40 & 1 & 4.5 & 4.5 & 36.4 \\
7.50 & 1 & 4.5 & 4.5 & 40.9 \\
7.70 & 1 & 4.5 & 4.5 & 45.5 \\
7.75 & 1 & 4.5 & 4.5 & 50.0 \\
7.90 & 1 & 4.5 & 4.5 & 54.5 \\
\hline
\end{tabular}




\begin{tabular}{|lllll|}
\hline 8.00 & 2 & 9.1 & 9.1 & 63.6 \\
8.25 & 3 & 13.6 & 13.6 & 77.3 \\
8.60 & 1 & 4.5 & 4.5 & 81.8 \\
8.70 & 1 & 4.5 & 4.5 & 86.4 \\
10.00 & 1 & 4.5 & 4.5 & 90.9 \\
10.15 & 1 & 4.5 & 4.5 & 95.5 \\
10.60 & 1 & 4.5 & 4.5 & 100.0 \\
Total & 22 & 100.0 & 100.0 & \\
\hline
\end{tabular}

Annex 2: Seed width mm.

\begin{tabular}{|lllll|}
\hline Valid & Frequency & Percent & Valid Percent & Cumulative Percent \\
3.05 & 1 & 4.5 & 4.5 & 4.5 \\
3.25 & 1 & 4.5 & 4.5 & 9.1 \\
3.70 & 1 & 4.5 & 4.5 & 13.6 \\
3.95 & 1 & 4.5 & 4.5 & 18.2 \\
4.45 & 1 & 4.5 & 4.5 & 22.7 \\
4.50 & 1 & 4.5 & 4.5 & 27.3 \\
4.60 & 1 & 4.5 & 4.5 & 31.8 \\
4.85 & 1 & 4.5 & 4.5 & 36.4 \\
4.90 & 1 & 4.5 & 4.5 & 40.9 \\
5.00 & 1 & 4.5 & 4.5 & 45.5 \\
5.05 & 1 & 4.5 & 4.5 & 50.0 \\
5.15 & 1 & 4.5 & 4.5 & 54.5 \\
5.40 & 1 & 4.5 & 4.5 & 59.1 \\
5.65 & 1 & 4.5 & 4.5 & 63.6 \\
5.80 & 1 & 4.5 & 4.5 & 68.2 \\
5.90 & 2 & 9.1 & 9.1 & 77.3 \\
5.95 & 2 & 9.1 & 9.1 & 86.4 \\
6.25 & 1 & 4.5 & 4.5 & 90.9 \\
8.00 & 1 & 4.5 & 4.5 & 95.5 \\
9.30 & 1 & 4.5 & 4.5 & 100.0 \\
Total & 22 & 100.0 & 100.0 & \\
\hline
\end{tabular}

Annex 3: Seeds / kg

\begin{tabular}{|lllll|}
\hline Valid & Frequency & Percent & Valid Percent & Cumulative Percent \\
8700.00 & 1 & 4.5 & 5.6 & 5.6 \\
13000.00 & 1 & 4.5 & 5.6 & 11.1 \\
13500.00 & 1 & 4.5 & 5.6 & 16.7 \\
16000.00 & 1 & 4.5 & 5.6 & 22.2 \\
\hline
\end{tabular}




\begin{tabular}{|c|c|c|c|c|}
\hline 17000.00 & 1 & 4.5 & 5.6 & 27.8 \\
\hline 17500.00 & 1 & 4.5 & 5.6 & 33.3 \\
\hline 22500.00 & 2 & 9.1 & 11.1 & 44.4 \\
\hline 24000.00 & 1 & 4.5 & 5.6 & 50.0 \\
\hline 26000.00 & 1 & 4.5 & 5.6 & 55.6 \\
\hline 26500.00 & 1 & 4.5 & 5.6 & 61.1 \\
\hline 27500.00 & 1 & 4.5 & 5.6 & 66.7 \\
\hline 28000.00 & 1 & 4.5 & 5.6 & 72.2 \\
\hline 33000.00 & 1 & 4.5 & 5.6 & 77.8 \\
\hline 34000.00 & 1 & 4.5 & 5.6 & 83.3 \\
\hline 42000.00 & 1 & 4.5 & 5.6 & 88.9 \\
\hline 55000.00 & 1 & 4.5 & 5.6 & 94.4 \\
\hline 70000.00 & 1 & 4.5 & 5.6 & 100.0 \\
\hline Total & 18 & 81.8 & 100.0 & \\
\hline Missing & System 4 & 18.2 & & \\
\hline Total & 22 & 100.0 & & \\
\hline
\end{tabular}

Annex 4: Pod length cm.

\begin{tabular}{|lllll|}
\hline Valid & Frequency & Percent & Valid Percent & Cumulative Percent \\
9.00 & 1 & 4.5 & 4.5 & 4.5 \\
11.50 & 1 & 4.5 & 4.5 & 9.1 \\
12.00 & 2 & 9.1 & 9.1 & 18.2 \\
14.00 & 2 & 9.1 & 9.1 & 27.3 \\
14.50 & 2 & 9.1 & 9.1 & 36.4 \\
15.00 & 3 & 13.6 & 13.6 & 50.0 \\
16.00 & 3 & 13.6 & 13.6 & 63.6 \\
16.50 & 3 & 13.6 & 13.6 & 77.3 \\
18.00 & 2 & 9.1 & 9.1 & 86.4 \\
19.00 & 1 & 4.5 & 4.5 & 90.9 \\
20.00 & 1 & 4.5 & 4.5 & 95.5 \\
24.00 & 1 & 4.5 & 4.5 & 100.0 \\
Total & 22 & 100.0 & 100.0 & \\
\hline
\end{tabular}

Annex 5: Pod width mm. frequencies

\begin{tabular}{|lllll|}
\hline Valid & Frequency & Percent & Valid Percent & Cumulative Percent \\
1.00 & 1 & 4.5 & 4.5 & 4.5 \\
1.10 & 1 & 4.5 & 4.5 & 9.1 \\
1.20 & 2 & 9.1 & 9.1 & 18.2 \\
1.35 & 1 & 4.5 & 4.5 & 22.7 \\
\hline
\end{tabular}




\begin{tabular}{|lllll|}
\hline 1.40 & 1 & 4.5 & 4.5 & 27.3 \\
1.45 & 1 & 4.5 & 4.5 & 31.8 \\
1.50 & 1 & 4.5 & 4.5 & 36.4 \\
1.60 & 1 & 4.5 & 4.5 & 40.9 \\
1.80 & 1 & 4.5 & 4.5 & 45.5 \\
1.85 & 1 & 4.5 & 4.5 & 50.0 \\
1.95 & 1 & 4.5 & 4.5 & 54.5 \\
2.10 & 2 & 9.1 & 9.1 & 63.6 \\
2.20 & 1 & 4.5 & 4.5 & 68.2 \\
2.25 & 1 & 4.5 & 4.5 & 72.7 \\
2.30 & 2 & 9.1 & 9.1 & 81.8 \\
2.45 & 1 & 4.5 & 4.5 & 86.4 \\
2.50 & 1 & 4.5 & 4.5 & 90.9 \\
2.75 & 1 & 4.5 & 4.5 & 95.5 \\
2.90 & 1 & 4.5 & 4.5 & 100.0 \\
Total & 22 & 100.0 & 100.0 & \\
\hline
\end{tabular}

\section{References}

[1] Al-Rawi , Khashi Mahmood , Bdulaziz Khalaf Allah . 1980. DESIGNING AND ANAYSIS OF AGRICULTURAL EXPERIMENTS. University Of Mosul Press. Iraq.

[2] Hughes CE, Harris SA. (1998). A SECOND SPONTANEOUS HYBRID IN LEUCAENA (LEGUMINOSAE, MIMOSOIDEAE). Plant Systematics and Evolution 212:53-77.

[3] Hughes, Colin E. (1998). LEUCAENA A GENETIC RESOURCES HANDBOOK. Oxford Forestry Institute Department of Plant Sciences, University Of Oxford. PP: 40.

[4] Hughes, Colin E. (1998). LEUCAENA A GENETIC RESOURCES HANDBOOK. Oxford Forestry Institute Department of Plant Sciences, University Of Oxford.

[5] Jones RJ. 1994. MANAGEMENT OF ANTI-NUTRITIVE FACTORS - WITH SPECIAL REFERENCE TO LEUCAENA. Forage Tree Legumes in Tropical Agriculture. 216-231; 38 Refs.

[6] Marcos Barros-Rodríguez1, Carlos A. Sandoval-Castro1, Javier Solorio-Sánchez1, Luis A. Sarmiento-Franco1 . , R. Rojas-Herrera. (2014). LEUCAENA LEUCOCEPHALA IN RUMINANT NUTRITION TROPICAL AND SUBTROPICAL AGROECOSYSTEMS: 173 183.

[7] Meena Devi VN1, Ariharan VN2 and Nagendra Prasad P3. (2013). NUTRITIVE VALUE AND POTENTIAL USES OF LEUCAENA LEUCOCEPHALA AS BIOFUEL - A MINI REVIEW. Research Journal Of Pharmaceutical, Biological And Chemical Volume 4 Issue 1 Page No. 515.

[8] Sadawe, Mohamed Zaky Abdel-Latif Zayed. (2015). PHYTOCHEMICAL AND MUTAGENESIS STUDIES OF NEOLAMARCKIA CADAMBA AND LEUCAENA LEUCOCEPHALA .Phd Of Science (Forestry). Universiti Malaysia Sarawak.

[9] Shaik, Noor Mahammad . 2009. MOLECULAR CLONING AND CHARACTERIZATION OF LEUCAENA LEUCOCEPHALA B-GLUCOSIDASE, A FAMILY 1 GLYCOSYL HYDROLASE for The Degree Of Doctor Of Philosophy In Biotechnology Pp 19.

*Corresponding author.

E-mail address: dryounisalbugg@ gmail.com 